\title{
Modelling the value of wetlands in the Kilombero Valley, Tanzania, using community preferences
}

\author{
F. Mombo ${ }^{1,2}$, S. Speelman ${ }^{1}$, D. Phillip ${ }^{2}$ \& G. van Huylenbroeck ${ }^{1}$ \\ ${ }^{1}$ University of Ghent, Ghent, Belgium \\ ${ }^{2}$ Sokoine University of Agriculture, Morogoro, Tanzania
}

\begin{abstract}
Wetland degradation has recently received considerable attention in research. Although wetlands are valuable ecosystems, their actual value is difficult to measure because the services they provide do not have market values. The current study tries to define the value of wetlands in the Kilombero Valley, central Tanzania. Choice modelling is used to determine communities' preferences over wetland conditions associated with various management options. The results show that the inhabitants of the Kilombero Valley desire improvements in the wetland's conditions, suggesting that the ongoing degradation is not socially optimal. Local farmers are however highly dependent on the wetland for their livelihood. In order to reduce pressure on wetlands, it is therefore necessary and imperative to explore the options of alternative income generating activities and the application of proper technologies to improve efficiency and effectiveness in crop production.
\end{abstract}

Keywords: wetlands, choice modelling, valuation and willingness to pay.

\section{Introduction}

In recent years, degradation of wetlands has received considerable attention in research. While in the past, wetlands were mostly neglected because they were considered as marginal areas, authors like Fischer [1] and Turner et al. [2] have recognized their importance. Wetlands play a unique role as ecosystem and provide diverse services to communities such as climate regulation, flood control and provision of food and fiber. To preserve the functions played by wetlands a sustainable management is of paramount importance. One of the prerequisites for 
sound management of natural resources is a correct valuation [3, 4]. It is necessary to know the value of products and services accrued from wetlands to be able to ensure sustainable management of these vital ecosystems throughout the world $[5,6]$. Given this context the valuation of wetland services has recently been the subject of study in many countries both in developing and developed world [7-9]. Because the services provided by wetlands are often not traded in the market most research was based on non-market valuation techniques such as Contingent valuation, Travel Cost Methods, Hedonic Pricing and others [10]. Other issues which constrain proper management of wetlands are the lack of knowledge of different stakeholders (farmers, conservationists, recreationists, etc.) and their values and attitudes and acknowledgement of the conflicting multiple objectives of stakeholders. Community involvement in the formulation of wetland management plans could provide policy alternatives that are more acceptable to the community. It is therefore interesting to incorporate stakeholder preferences and multiple objectives to evaluate management options [11, 12].

This study considers the Kilombero valley wetlands in Tanzania. As in other areas in Africa wetlands play a significant role in the livelihoods of the rural communities of this region [13]. The ability of wetlands to store water during the wet season and release it during the dry season provides farmers living in semiarid areas opportunities to grow crops all-year round. This improves their food security and incomes. Besides crop production, wetlands also provide other services that support human welfare such as livestock grazing and watering, water supply, fishing and natural products [13]. Degradation of wetlands can cause loss of these functions. Following several authors $[5,8,12,14]$ we use a Choice Experiment (CE) to expose public preferences over the range of possible future landscape configurations for the Kilombero wetlands. The method has the advantage to enable us to show through various models the unobserved and unconditional heterogeneity in preferences. As indicated by various authors [11, $14,15]$ the conflicting multiple objectives of stakeholders, make it important to recognize the distinct groups showing different concerns. This information is important for policy makers during policy formulation $[16,17]$. In our study the utilities of different individuals who are primary and secondary users of wetland services are estimated and used to see how environmental and socioeconomics attributes influence utilities and hence households willingness to pay for an improved status of the wetlands. The results of this study can be used by policy makers and other development practitioners in developing countries to see how wetlands can be sustainably managed under these typical conditions of diverse preferences of the users and varying wetlands attributes. Moreover in the establishment of management plans the $\mathrm{CE}$ can also be used as a conflict avoidance tool or conflict resolution tool [12].

\section{The methodology}

\subsection{The study area}

This study was conducted from August 2009 to March 2010 in the Kilombero Wetlands in Morogoro region, South Tanzania. The wetlands are located 
between the Udzungwa Mountains and the Mahenge escarpment. The valley is divided by the Kilombero River and falls within two districts of Kilombero and Ulanga. The wetland area covers $7,967 \mathrm{~km}^{2}$ with a catchment's area of about $40,000 \mathrm{~km}^{2}$. Many rivers, permanent and seasonal, feed the floodplain. The area is characterised by a sub-humid tropical climate with an annual rainfall of about $2000-3100 \mathrm{~mm}$. It has two seasons of rains where the long rains are from March to May and short ones from October to December. Temperatures normally vary from $20^{\circ} \mathrm{C}$ to $30^{\circ} \mathrm{C}$.

\subsection{The design of the choice experiment and data collection method}

Choice experiments are based on two important theories: the traditional microeconomic theory of consumer behaviour and random utility theory [7, 18]. In this study the various wetland attributes, used to design wetland management options, were identified through consultations with experts at Sokoine university of Agriculture (SUA) and with officials of various government departments and NGOs. In order to ensure that these attributes are realistic various focus group discussions with communities around the wetlands were conducted. The government officials, experts and locals in this way identified the attributes which they consider to be most important for wetlands management. A similar identification process was found in several studies $[8,12,14]$. The definition and levels of these attributes are described in table 1 .

The flood plain area attribute was considered important by the stakeholders because the areas cultivated by farmers are more and more in conflict with the wetlands. The main effect of crop cultivation is soil erosion, which has resulted into siltation of dams downstream. This attribute was also included in the study of Westerberg et al. [12]. Biodiversity was included as attribute because most communities depend on fishing as one of their sources of income and food. Moreover, tourism activities, a sector that contributes a lot to the Gross Domestic Product (GDP) of the country, is dependent on the occurrence of animal species. To continue having all these benefits it is important to conserve the biodiversity in this area. Biodiversity is a typical attribute to include in the evaluation of management plans. It is found in many studies $[8,11,12,14,15]$. The area under controlled livestock farming and the vegetation cover in the catchment areas were also identified as wetland attributes. This is because there is agreement on the negative effects of free range livestock farming and deforestation. It is argued by the officials that the actual number of livestock exceeds the carrying capacity of the wetland, resulting in negative externalities such a decrease in water retaining capacity of soils and drying of swamps and rivers. The vegetation cover is most affected by deforestation for timber extraction and fuel wood utilization. More than $90 \%$ of the households in the Kilombero district use fire wood for cooking. Another problem that causes deforestation is the expansion of farming area by the local people. A number of problems are related to deforestation: mainly loss of water retention of the soils and erosion. The payment attribute is included in the experiment to be able to measure the willingness to pay for changes in the other attributes. An addition to the water bill was chosen because 
Table 1: The attributes and levels for Various Management option in Kilombero Valley wetlands.

\begin{tabular}{|c|c|c|}
\hline Attributes & Definition & Management levels \\
\hline $\begin{array}{l}\text { Flood plain } \\
\text { area }\end{array}$ & $\begin{array}{l}\text { Flood plain area that } \\
\text { remains unconverted } \\
\text { into agriculture }\end{array}$ & $\begin{array}{l}\text {-Bad: Increase of area under shifting } \\
\text { cultivation and decrease in seasonal } \\
\text { and permanently flooded streams, } \\
\text { swamps and ponds in the flood plain } \\
\text {-Status quo of the area under shifting } \\
\text { cultivation and seasonal and } \\
\text { permanent streams, swamps and } \\
\text { ponds in the flood plain } \\
\text {-Good: Decrease of area under } \\
\text { shifting cultivation and increase in } \\
\text { seasonal and permanently flooded } \\
\text { streams, swamps and ponds in the } \\
\text { flood plain. }\end{array}$ \\
\hline $\begin{array}{l}\text { Area under } \\
\text { free range } \\
\text { grazing }\end{array}$ & $\begin{array}{l}\text { Wetland area that is } \\
\text { used for free range } \\
\text { grazing }\end{array}$ & $\begin{array}{l}\text {-Bad: Continued increase in area } \\
\text { under free range grazing } \\
\text {-Status quo of area under free range } \\
\text { grazing } \\
\text {-Good: Protecting some parts of the } \\
\text { wetland area from grazing }\end{array}$ \\
\hline $\begin{array}{l}\text { Water } \\
\text { catchment } \\
\text { area }\end{array}$ & $\begin{array}{l}\text { Catchment area that } \\
\text { remains covered by } \\
\text { the vegetation }\end{array}$ & $\begin{array}{l}\text {-Bad: Continued decline in vegetation } \\
\text { cover } \\
\text {-Status quo: current vegetation cover } \\
\text { is maintained. } \\
\text {-Good: Increase of area under } \\
\text { vegetation cover from current state by } \\
30 \%\end{array}$ \\
\hline Biodiversity & $\begin{array}{l}\text { The number of } \\
\text { different species of } \\
\text { plants, wild animals } \\
\text { and fish and their } \\
\text { population levels. }\end{array}$ & $\begin{array}{l}\text {-Low: Probability to catch/see plants } \\
\text { and animal species decreases } \\
\text {-Status quo } \\
\text {-High: Probability to catch/see plants } \\
\text { and animal species increases. }\end{array}$ \\
\hline Payment & $\begin{array}{l}\text { A one off payment } \\
\text { to go to the wetland } \\
\text { unit in the Wildlife } \\
\text { department }\end{array}$ & $\begin{array}{l}\text { Percent increase of the amount paid as } \\
\text { water dues. } \\
0 \% 5 \% 10 \% 15 \%\end{array}$ \\
\hline
\end{tabular}

a link between the wetland management and water delivery is perceived. Moreover the local communities and experts agreed that water bills would constitute a convenient way to get most people to pay the costs of wetlands management. It was decided to use percentage increase in water bills so as to make each person pay depending on water use capacity as the payment of the bills is per cubic meter used. 
Using SAS macros (see [19] for details) a generic D-optimal choice design was developed. From the attributes and their levels 9 choice cards, each with 3 management options and 1 status quo option, were constructed. To reduce the burden upon the respondents the 9 sets were blocked into 3 . In this way each individual has to complete 3 choice tasks.

Data were collected face to face which gave us the opportunity to clearly explain the choice sets. In order to enhance this, cheap talk was devised following Nam and Bennet [9] who argue that in developing countries' situation, cheap talk makes it simple for people to grasp the management options and their levels. During the cheap talk various photos were portrayed to demonstrate the three status levels of the wetlands. The photos were taken from places where the destruction was evident to show what it meant by bad and those from conserved areas to show what it meant by good and to some places where the destruction was average to show the status quo as an average condition country wide. In the cards to be chosen the words were shortened to make an individual choice easy and meaningful. The design of the card is as portrayed in table 2 .

Table 2: $\quad$ Choice experiment card for various management options.

\begin{tabular}{|c|c|c|c|c|}
\hline & Option A & Option B & Option C & \multirow{6}{*}{$\begin{array}{l}\text { Neither } \\
\text { management } \\
\text { option A, option B } \\
\text { nor management } \\
\text { option C }\end{array}$} \\
\hline Biodiversity & High & Low & Low & \\
\hline $\begin{array}{l}\text { Water } \\
\text { catchment area }\end{array}$ & Good & $\mathrm{Bad}$ & $\begin{array}{l}\text { No } \\
\text { change }\end{array}$ & \\
\hline Flood plain area & $\mathrm{Bad}$ & $\begin{array}{l}\text { No } \\
\text { change }\end{array}$ & $\mathrm{Bad}$ & \\
\hline $\begin{array}{l}\text { Area under free } \\
\text { range grazing }\end{array}$ & $\mathrm{Bad}$ & $\begin{array}{l}\text { No } \\
\text { change }\end{array}$ & Good & \\
\hline Payment & $10 \%$ & $15 \%$ & $5 \%$ & \\
\hline $\begin{array}{l}\text { I will prefer: } \\
\text { (Please tick as ap }\end{array}$ & $\begin{array}{l}\text { Option A } \\
\text { ropriate) }\end{array}$ & Option B & Option $\mathrm{C}$ & Neither.... \\
\hline
\end{tabular}

A total of 408 households were randomly selected for the interview. The sampling frame consisted of all rural communities in and around the Kilombero wetlands, who are the primary users of the wetlands. As the study meant to advice the policy makers on how the wetlands can be sustainably managed in the whole country of Tanzania it was seen important to extend the sample into secondary users of the wetland and hence households in Morogoro municipal were randomly selected to represent the secondary users of the wetlands.

\subsection{Data analysis}

The responses from the $\mathrm{CE}$ were analysed using a Random Parameter Multinomial Logit Model. In this type of model which, unlike the conditional logit model, is not based on the Independent from Irrelevant Alternative (IIA) assumption, unobserved heterogeneity in preferences across respondents can be accounted for $[18,20]$. This is important because an understanding of who will be affected by a policy change in addition to understanding the aggregate 
economic value associated with such changes is necessary $[8,16]$. Furthermore the model can explicitly account for the repeated nature of the choices made [21]. In practice a person faces a choice among the alternatives in choice set $\mathrm{j}$ on each of the occasions they make a choice. The utility that respondent $\mathrm{n}$ obtains from alternative $\mathrm{j}$ in choice situation $\mathrm{t}$ consists of a systematic and a stochastic part (Ref. equation 1)

$$
U_{n j t}=\alpha_{n j}+\gamma_{j} S_{n}+\beta_{n} x_{n j t}+\varepsilon_{n j t}
$$

where $x_{n j t}$ is a vector of attributes and $S_{n}$ is a vector of socio-economic characteristics. The alternative specific intercept $\alpha_{n j}$ captures an intrinsic preference for the alternative and $\gamma_{j} S_{n}$ captures systematic preference heterogeneity as a function of individual characteristics. The coefficient vector $\beta_{n}$ varies among the population with density $\mathrm{f}(\beta \mid \theta)$, where $\theta$ is a vector of the true parameters of the taste distribution.

If the $\varepsilon_{\text {njt }}$ are IID type I extreme value, we have a random parameter logit model [22]. The conditional probability of alternative $\mathrm{j}$ for individual $\mathrm{n}$ in choice situation $\mathrm{t}$ is then (Ref. equation 2 ).

$$
P_{n}\left(j t \beta_{n}\right)=\frac{\exp \left(\alpha_{j n}+\gamma_{j} S_{n}+\beta_{n} x_{n j t}\right)}{\sum_{i \in A_{k}} \exp \left(\alpha_{i n}+\gamma_{i} S_{n}+\beta_{n} x_{n i t}\right)}
$$

where $A k=\{A 1, \ldots, A N\}$ is the choice set.

In this paper we will use a simulated maximum likelihood estimator, using Halton draws, to estimate the models [20]. It is furthermore also necessary to make an assumption regarding the distribution of each of the random coefficients. In principle any distribution could be applied. However, the choice is often limited by difficulty of model estimation and availability of econometric software. Following [8] we use a normal distribution for the random coefficients. Even though unobserved heterogeneity can be accounted for in the RPL model, the model fails to explain the sources of heterogeneity. Therefore we include interactions of respondent-specific socio-economic and attitudinal characteristics with choice specific attributes. In this way our model is able to pick up preference variation in terms of both unconditional taste heterogeneity (random heterogeneity) and individual characteristics (conditional heterogeneity), and hence the model fit is improved [8, 23]. The characteristics selected were education level, income, ownership of land for farming, ownership of livestock, and gender.

\section{Results and discussion}

\subsection{Socio-economic characteristics of the respondents}

The sample consisted of individuals with various socio-economic characteristics. Most $(60 \%)$ of the respondents followed at least primary education, only $4 \%$ completed adult education and $20 \%$ completed secondary education. The remaining $26 \%$ had a higher education degree. The majority of the households 
(52\%) had an income between 100000 and 1 million TAS (1\$ is approximately equivalent to 1450 Tanzanian Shillings, TAS). It is interesting to note that the persons with the highest educational level and highest household income lived in Morogoro Municipality. Gender distribution was nearly even, with male respondents representing $58 \%$ of the respondents. The respondent's age ranged from 17 to 81 years old.

\subsection{Communities preferences over management option}

The results of the random parameter model without interaction terms reveal that in general people from Morogoro and Kilombero are in favour of better management strategies for the wetlands. This is in line with other studies [12, 15], who also found a positive public attitude towards wetland conservation. Here this can be deduced from the positive and significant coefficients for all attributes. For each attribute one has an estimated coefficient for the mean of the distribution, and one for the variance of the distribution. Associated with each of these is an estimate of the standard error, so one can draw standard inferences about the significance of the coefficient. If the estimate of the variance is not different from zero, then one can infer that the preference parameter is constant across the population. If the mean coefficient is zero, but the variance estimate is significant one cannot infer that the attribute does not affect choice, but rather that there is a diversity of preferences, both positive and negative. For an attribute to be declared as having no impact on choices, both the estimate of the mean and the variance has to be insignificantly different from zero. In contrast to the other attributes the coefficient for the payment vehicle is negative, meaning that a higher price reduces the probability of a choice option being chosen. From the four attributes biodiversity has the highest coefficient. This might be due to the communities' dependency on wild game, tourism and fishing (Table 3). Tanzania National Park Authority (TANAPA) which manages Udzungwa National Park has highly invested in conservation of the area through awareness creation and legal enforcement. Furthermore one has to note that $25 \%$ of Kilombero council income comes from fishing activities, which for sure also has implication on household income for most of the communities around Kilombero Valley. Finally fish and game meat still have an important role in the diets in the region which also leads to a high preference for a management option that would increase the biodiversity of the Kilombero Valley ecosystems.

The following attribute after biodiversity is the increase in vegetation cover in the catchment areas. This is an interesting finding, since it is an indication that the national campaign on tree planting and vegetation conservation has helped to create awareness in Tanzania's communities on the value of forests and trees. The vegetation cover in catchment areas and other forested land in Tanzania is in an alarming situation. Data from UN [24] suggest that the deforestation rate is currently at $412,000 / \mathrm{ha} / \mathrm{yr}$ and the forested land is 34 million hectares. It is therefore encouraging to have this general preference from the communities which indicates that if there would be proper programming in forest management there is a willingness among communities to cooperate into improving the 
Table 3: The Basic Random Parameter Logit Model and with interaction estimates for wetlands management attributes.

\begin{tabular}{|l|c|c|c|c|}
\hline & \multicolumn{3}{|c|}{ The basic model } & \multicolumn{2}{c|}{ The model with interaction } \\
\hline Attribute & Coefficient & Coef. std(s.e) & Coefficient & Coef std(s.e) \\
\hline Biodiv & $2.07^{* * *}$ & $13.15(0.15)$ & $2.15^{* * *}$ & $12.40(0.16)$ \\
\hline Catchment & $0.80^{* * *}$ & $15.02(0.11)$ & $2.21^{* * *}$ & $15.76(0.24)$ \\
\hline Flood plain & $0.71^{* * *}$ & $8.37(0.10)$ & $0.69^{* * *}$ & $9.10(0.11)$ \\
\hline Free range & $0.37^{* * *}$ & $8.30(0.10)$ & $0.23^{* *}$ & $9.41(0.10)$ \\
\hline Payment & $-0.004^{* * *}$ & - & $-0.004^{* * *}$ & - \\
\hline Flood Plain*Landown & - & - & $-0.004^{* *}$ & - \\
\hline Flood Plain*High inc & - & - & $4.39^{* * *}$ & - \\
\hline Catchm*Gender & - & - & -0.33 & - \\
\hline Biodiv*Landown & - & - & $-0.03^{* *}$ & - \\
\hline Biodiv*High inc & - & - & 0.03 & - \\
\hline Catchm*Low edu & - & - & $-0.62^{* * *}$ & - \\
\hline Biodiv*Livest Own & - & - & $-0.004 * * *$ & - \\
\hline $\begin{array}{l}\text { Observations } \\
\text { Log likelihood }\end{array}$ & 4884 & 4884 & -3124.054 & \\
Pseudo R Square & -3204.770 & 0.035 & \\
Chi-Square & 0.036 & 4 & 227.794 & \\
Degrees offreedom & 241.470 & 4 & 4 & \\
\hline
\end{tabular}

** Significant at $5 \%, * * *$ significant at $1 \%$

situation. Other studies also show that it is not the intention of the communities to cause deforestation, but that they have no alternatives for firewood as energy source for cooking [25-27]. It is up to the government to come up with policies that provide alternatives to people.

The smallest coefficient is found for the free range grazing attribute. Probably the fact that a decrease in free ranging area is perceived as a call for a reduction in the stock size; which would directly touch upon the livelihood of many of the respondents could explain this. Policy makers should always consider such impacts on livelihoods when coming up with policies. One should consider that livelihoods might be affected when certain strategies are sought for the improvement of the wetlands status. Much of this will be noted in the model where some socio-economic characteristics were interacted with some attributes.

After having the general results from the basic model we extended it by including interaction of some of the attributes with certain socio-economic characteristics. After extensive testing of various interactions of the four wetland management attributes with the respondents' social, economic and attitudinal characteristics collected in the survey, the model including interactions with education level, income level, ownership of land for farming, ownership of livestock, and gender was found to best fit the data .

The results of the interactions confirm that livelihoods affect preferences of respondents. The probability that respondents who owned crop farms in the valley choose for a decrease in shifting cultivation is for example smaller than that of the average respondents (negative coefficient of flood plainlandownership interaction). This observation shows that policy makers should 
carefully think about the policies they formulate and how they affect different groups. As a matter of advice as was noted in the scholarly documentation that in order to bring cooperation then the issue of who benefit and who incur cost into such undertakings should guide the conservation strategies [2, 28, 29]. The research revealed that while the crop farmers are less in favour of conservation practices, households with high incomes which are mostly from Morogoro municipal are clearly opting for an increase in flooded area throughout the year. This is not surprising because they depend on the flood plains for their water supply and have other alternatives for food and income sources, which the farmers who live in the floodplains do not have. A similar reasoning can be made for the biodiversity-land ownership interaction. For many of the attributes our study thus confirms the findings of [15], who found that livelihood strategies and location influence the preferences for wetland conservation. They therefore decided that the spatial distribution of stakeholder preferences for conservation and development is very important in shaping the wetland related policy in unprotected areas. The interaction between the vegetation cover attribute and education offers another important finding. Those who are lowly educated are far less in favour of decreases in tree extraction. This is thought to be due to the fact that people in the rural areas make a high proportion of illiterate and uninformed folks about the values of vegetation cover in wetlands. Also, they are primarily dependent on these resources for sustaining their livings in terms of cash, energy and habitation. This puts them into a dilemma of whether to conserve the vegetation or harvest it to sustain their living. As it has been discussed in the general findings it is therefore advised to come up with strategies that would help to reduce pressure on these areas. Although the results were marginally significant at $10 \%$, gender also shows a distinct pattern, where males are opting for low status wetlands management in terms of vegetation cover in the catchment area; this is partly contributed by how conservation programmes are carried on in Tanzania. It is reported by Songorwa and Sikira [30] that more women are involved in these programs. Another reason might be that men as main bread earners have more insight in the potential livelihood effects. Studies by Ellis et al. [31] and URT [32] support this argument.

\subsection{Determination of willingness to pay}

The willingness to pay and implied ranking from the general basic model for each attribute was calculated following [33] (see table 4). In terms of ranking, biodiversity goes first followed by increase in catchment area vegetation cover. The details are as we have earlier discussed when we were determining communities' preferences. The overall marginal willingness to pay per household for improving all attributes is $0.683 \mathrm{USDHh}^{-1} \mathrm{month}^{-1}$. This is a very encouraging amount for a community in a developing country like Tanzania. Moreover as of to date no budget goes specifically to the conservation activities in our wetlands ecosystems, institutionalisation of this payment could already make a big difference.

It is however important to come up with proper incentive mechanisms that would bring all stakeholders together into conserving the wetlands. The possible 
way to do this is through application of economic instruments, an avenue which is available since the country has a specific regulation in the newly enacted Environmental Management Act of 2005 [35].

Table 4: Willingness to pay and implied rankings in Management options of Kilombero Valley Wetlands.

\begin{tabular}{|l|c|c|r|}
\hline Attribute & Coeff & Implied Ranking & WTP (USD) $\mathrm{Hh}^{-1} \mathrm{Month}^{-1}$ \\
\hline Biodiversity & 2.071 & 1 & 0.357 \\
\hline Catchment area & 0.804 & 2 & 0.139 \\
\hline Flood plain area & 0.714 & 3 & 0.123 \\
\hline $\begin{array}{l}\text { Free range } \\
\text { grazing }\end{array}$ & 0.373 & 4 & 0.064 \\
\hline
\end{tabular}

1 USD is equivalent to 1450 TAS

\section{Conclusion}

In general there is a preference among communities to improve management of the wetlands, which reveals that the inhabitants of the Kilombero Valley and Morogoro Municipality desire improvement of the wetland's conditions.This suggests that the ongoing degradation is socially not optimal. Secondly, looking at the attributes associated with the wetlands, the study shows that land ownership and cultivation type are very important factors. Farmers are more reluctant to shift their practice and to give up some of their land in order to enhance the conditions of the wetland because this would drastically affect their household income. This being the case it is therefore important for the policy makers to have enough information of what are the really causes of the wetlands degradation in specific areas before they develop conservation strategies. Communities' involvement in finding such strategies is important to ensure effectiveness and sustainability of the strategies to be developed. Besides of ensuring sustainability, such approach would also reduce the cost of management of the wetlands as takes into account the best interest of all stakeholders. The study therefore recommends that in order to bring participation in wetlands conservation, the policies should consider compensation of the negatively affected group such as small farmers, whose income is entirely dependent on shifting cultivation. It is further recommended that other income generating activities which would reduce the pressure on the wetlands should be explored. But even more, investing in the development of proper technologies that would improve efficiency and effectiveness in crop production should be pursued.

\section{References}

[1] Fischer, G., Land and Water Use of Wetlands in Africa: Economic Values of African Wetlands. Interim Report No. IR- 02-063. Luxemburg, Austria, 2002. 
[2] Turner, R.K., van den Bergh, J.C.M., Soderqvist, T, Barendregt, A., van der Straaten ,J; Maltby, E \& van Ierland, E.C. Ecological-economic analysis of wetlands: scientific integration for management and policy. Ecol Econ, 35, pp. 7-23, 2000.

[3] Pearce, W.D. \& Tunner, R.K., Economics of Natural Resources and the Environment. BPCC Wheatons Ltd: Exeter- Britain, pp. 378, 1990.

[4] Turpie, J. K., The existence value of biodiversity in South Africa: how interest, experience, knowledge, income and perceived level of threat influence local willingness to pay. Ecological Economics, 46 (2), pp. 199216, 2003.

[5] Birol, E., \& Cox, V., Using choice experiments to design wetland management programmes: The case of Severn Estuary wetland, UK. Journal of Environmental Planning and Management, 50, pp. 363-380, 2007.

[6] Jenkins W.A., Murray B.C., Kramer R.A. \& Faulkner, S. P. Valuing ecosystem services from wetlands restoration in the Mississippi Alluvial Valley. Ecological Economics, 69, pp. 1051-1061, 2010

[7] Alpizar, F., Carlsson, F. \& Martinsson, P., (eds). Using Choice Experiments for Non-Market Valuation, Working Papers in Economics, No. 52, Department of Economics, Gothenburg University, 2001.

[8] Birol E., Karousakis K., \& Koundouri P., Using a choice experiment to account for preference heterogeneity in wetland attributes: The case of Cheimaditida wetland in Greece. Ecological economics, 60, pp. 145 - 156, 2006.

[9] Nam, D and Bennet, J., Estimating wetland biodiversity values: a choice modelling application in Vietnam's Mekong River Delta. Environment and Development Economics, 14, pp. 163-186, 2008.

[10] Adamowicz, W., Louviere, J., \& Williams, M., Combining revealed and stated preference methods for valuing environmental amenities. Journal of Environmental Economics and Management, 26, pp. 271-292, 1994.

[11] Herath G., Incorporating community objectives in improved wetland management: the use of the analytic hierarchy process. Journal of Environmental Management, 70, pp. 263-273, 2004.

[12] Westerberg, V.H., Lifran, R., \& Olsen, S.B., To restore or not? A valuation of social and ecological functions of the Marais des Baux wetland in Southern France. Ecological Economics, 69, pp. 2383-2393, 2010.

[13] Jogo W., Hassan R., Balancing the use of wetlands for economic well-being and ecological security: The case of the Limpopo wetland in southern Africa. Ecological Economics, 69, pp. 1569-1579, 2010.

[14] Birol E., Hanley N., Koundouri P., \& Kountouris Y., Optimal management of wetlands: Quantifying trade-offs between flood risks, recreation, and biodiversity conservation. Water Resources Research, 45 (11426), 2009.

[15] Wattage, P., \& Mardle S., Stakeholder preferences towards conservation versus development for a wetland in Sri Lanka. Journal of Environmental Management, 77, pp. 122-132, 2005. 
[16] Boxall, P.C., \& Adamowicz, W.L., Understanding heterogeneous preferences in random utility models: a latent class approach. Environmental and Resource Economics, 23, pp. 421-446, 2002.

[17] Milon, W., \& Scrogin, D., Latent preferences and valuation of wetland ecosystem restoration. Ecological Economics, 56 (2), pp. 162-175, 2006.

[18] Louviere, J.J., Hensher, D.A. \& Swait, J.D., Stated choice methods: analysis and application. Cambridge University Press: Cambridge, U.K., 2000.

[19] Kuhfeld, W.F. "Marketing Research Methods in SAS.", Online:www.support.sas.com/resources/papers/tnote/tnote_marketresearch. html

[20] Carlsson, F., Frykblom, P., \& Liljenstolpe, C., Valuing wetland attributes: an application of choice experiments. Ecological Economics, 47, pp. 95$103,2003$.

[21] Rigby, D \& Burton, M., Capturing preference heterogeneity in stated choice models: a random parameter logit model of the demand for GM food. Discussion Paper Series No. 0319. School of Economic Studies: The University of Manchester, 2003.

[22] Train, K.E., Recreation demand models with taste differences over people. Land Economics, 74, pp. 230-239, 1998.

[23] Revelt, D., \& Train, K., Mixed logit with repeated choices: households' choice of appliance efficiency level. Review of Economics and Statistics, 53, pp. 647-657, 1998.

[24] UN, The Millennium Development Goals Report. New York, 2007.

[25] Holmes, C.M., Cultural variation, decision making, and local institutions: An examination of fuelwood use in western Tanzania. Society \& Natural Resources, 18, pp. 61-73, 2005.

[26] Naughton-Treves, L; Kammen, D.M \& Chapman, C., Burning biodiversity: Woody biomass use by commercial and subsistence groups in western Uganda's forests. Biological Conservation, 134, pp. 232-241, 2007.

[27] Lusambo, L. P., Economics of Household Energy in Miombo Woodlands of Eastern and Southern Tanzania. Ph. D. dissertation. University of Wales: Bangor, UK., pp 493, 2009.

[28] Costanza, R., Thinking Broadly About Costs and Benefits in Ecological Management; Integrated Environmental Assessment and Management. TBACAB, pp. 166-173, 2005.

[29] Birdyshaw, E. \& C .Ellis, Privatizing an open-access resource and environmental degradation. Ecological Economics, 61(2-3), 2007.

[30] Songorwa, A. and Sikira, A., Women participation and empowerment in community-based wildlife management: The case of serengeti regional conservation project, Tanzania. Annual meeting of the International Congress for Conservation Biology, Convention Center, Chattanooga, Online. www.allacademic.com/meta/p243744 index.html

[31] Ellis, A. Blackden M., Cutura, J.; MacCulloch, F. \& Seebens, H., (eds). Gender and Economic Growth in Tanzania; Creating Opportunities for Women. The World Bank: Washington, D.C., 2007. 
[32] United Republic Of Tanzania (URT), Draft Report on Annotated Outline For National Strategy For Growth And Reduction Of Poverty. Dar es Salaam, Tanzania, 2010.

[33] Hanley, N. \& Adamowicz, W., Using Choice Experiments to Value the Environment. Environmental and Resource Economics. 11(3-4), pp. 413428, 1998.

[34] United Republic Of Tanzania (URT), The Environmental Management Act. Dar es Salaam, Tanzania, 2005. 